\title{
Public Opinion on Problem Solving Skills
}

\author{
Gowri Manohari P, Sreeya B
}

\begin{abstract}
Problem Solving may incorporate scientific or deliberate tasks and can be a measure of a person's basic reasoning aptitudes. Critical thinking in brain science alludes to the way toward discovering answers for issues experienced in life. Solutions to these issues are typically circumstance or setting particular. Problem solving enables people to take a gander at circumstances from numerous sides, and after that envision a few distinctive approaches to react. This open procedure of reasoning presents thoughts and arrangements that grow the open doors for progress. The main objective of this study is to know about the problem-solving skills among the people. For the purpose of this study descriptive research is used to portray accurately the public opinion on problem solving skills. Convenient sampling method is used to collect the samples. 1859 samples - sample size. Independent variables are gender, educational qualification, age. Dependent variables are Problem solving process, choice of overcoming the problem, mean of level of agreeability towards Problem solving skills. Independent sample t test, chi square and ANOVA are the research tools used in this research. The findings of this study suggests that Problem solving ability is fundamental for everybody to prevail in their day to day life. It is concluded that each and every person should develop problem solving skill in them in order find solution for the problems they face in their life. Solving our problems then and there will help us to lead a peaceful life.
\end{abstract}

Keywords: problems, problem solving, skill, evaluation, overcoming, solution.

\section{INTRODUCTION}

The way toward working through subtle elements of an issue to achieve a solution. Problem Solving may incorporate scientific or deliberate tasks and can be a measure of a person's basic reasoning aptitudes. Critical thinking in brain science alludes to the way toward discovering answers for issues experienced in life. Solutions to these issues are typically circumstance or setting particular. The procedure begins with issue finding and issue forming, where the issue is found and improved. The subsequent stage is to produce conceivable arrangements and assess them. At long last an answer is chosen to be actualized and confirmed. Issues have an objective to be come to and how you arrive relies on issue introduction (Problem solving adapting style and abilities) and methodical analysis. Mental wellbeing experts consider the human critical thinking forms utilizing strategies, for example, thoughtfulness, behaviorism, reenactment, PC demonstrating, and try. Social clinicians investigate the individual condition relationship part of the issue and autonomous and reliant critical thinking strategies. Critical thinking has been characterized as a higher-arrange psychological process and scholarly capacity that requires the balance and control of more daily practice or key

Revised Manuscript Received on 14, October 2019.

Gowri Manohari P, B.B.A. L.LB.(Hons.), Saveetha School of Law, Saveetha Institute of Medical and Technical Sciences (SIMATS), Chennai, Tamilnadu, India.

Dr. Sreeya B, Associate Professor, Saveetha school of Law, Saveetha Institute of Medical and Technical Sciences (SIMATS), Chennai, Tamilnadu, India.(Email: sreeyab.ss1@ saveetha.com) aptitudes. Normal obstructions to critical thinking are mental develops that hinder our capacity to effectively tackle issues. These obstructions keep individuals from taking care of issues in the most proficient way conceivable. Five of the most widely recognized procedures and variables that scientists have distinguished as obstructions to Problem solving are affirmation inclination, mental set, practical fixedness, pointless requirements, and unessential information. In an ongoing examination directed by Larry Ferlazzo Students require more aptitudes in basic reasoning, correspondence and critical thinking. It is discovered that 4 out of 10 U.S students graduate without Problem solving aptitudes to deal with their work. The U.S. Bureau of Labor has as of late distinguished basic reasoning as a crude material for some imperative working environment abilities, including Problem solving and basic leadership. As indicated by an ongoing Wall Street Journal article, an investigation by Indeed.com found that the notices for basic reasoning in occupational postings have multiplied since 2009. This audit is upheld by the American Management Association Critical Skills Survey, which found that more than 70 percent of taking an interest supervisor distinguished Problem solving as a vital component of representative development. Problem solving enables people to take a gander at circumstances from numerous sides, and after that envision a few distinctive approaches to react. This open procedure of reasoning presents thoughts and arrangements that grow the open doors for progress. organizations that create problem solving expertise among the representatives can see an expansion in cooperation and efficiency, and a decrease in conflict. Problem solving ability is fundamental for everybody to prevail in their life.

\section{OBJECTIVES}

- To understand about the problem-solving skills among the people

- To know the association between the problemsolving process and age of the respondent

- To interpret the difference between the choice of overcoming problem and the gender

- To analyze the significant difference in the mean scores of level of agreeability towards Problem solving skills among the educational qualification groups

\section{LITERATURE REVIEW}

Ji Young Kim, Dae Soo Choi, Chang-Soo Sung and Joo Y. Park (2018) examined that Colleges take part in business training to build social esteem creation, through understudies' new open doors acknowledgment. Nonetheless, there are insufficient of experimental looks into on whether the present business enterprise instruction

Published By:

Blue Eyes Intelligence Engineering

\& Sciences Publication 
can be separated from other educational modules to enhance the open door acknowledgment process. This examination contends that it is imperative for psychological capacities to be shown as conduct when understudies in college are new open doors acknowledgment. Hamalainen, Raija, De Wever, Bram, Nissinen, Kari, Cincinnato (2017) demonstrated that the critical thinking abilities of grown-ups with a professional instruction and preparing (VET) foundation in innovation rich conditions (TREs) are regularly insufficient. Be that as it may, a few grown-ups with a VET foundation do have sound critical thinking abilities. The present examination gives understanding into the socio-statistic, business related, and regular daily existence factors that are related with a solid critical thinking execution. Maria Elena Oliveri, Renee Lawless \& Hillary Molloy (2017) examined the writing and the representative and workforce overviews rank community critical thinking (CPS) among the main 5 most basic abilities essential for accomplishment in school and the workforce. This paper gives a survey of the writing on CPS and related terms, including a dialog of their definitions, significance to advanced education and workforce achievement, and contemplations important to their appraisal. Duygu Ileriturk, Remzi Yavas Kincal (2016) This investigation is meant to survey the consequences of critical thinking abilities test in PISA of Turkey as far as sexual orientation, educational modules and kinds of school. The information was investigated by the methods for archive examination technique in this examination which has a subjective clear research outline. Andreas Rausch, Thomas Schley \& Julia Warwas (2015) This paper introduces that contemporary office work is ending up progressively difficult the same number of routine errands are mechanized or outsourced. The rest of the critical thinking exercises may likewise offer potential for deep rooted learning in the work environment. In this investigation, we broke down critical thinking in an office work setting utilizing an Internet-based, semiinstitutionalized journal to gather information near the procedure. Shelly Wismath, Doug Orr and Maggie Zhong (2014) The researcher in his paper says that critical thinking is a basic part of a far reaching 21 st century training. This examination explores the impression of understudies of taking a college liberal training course intended to create critical thinking aptitudes. We depict how the members in the examination made their own comprehension of what critical thinking aptitudes are and why they are vital. Abdullah Karakaya , Kasim Yilmaz (2013) The research paper is about fast change and broad rivalry, associations need to guarantee the steadiness of their hierarchical improvement (OD) exercises. The objective of this examination is to ask OD exercises dedicated to tackling issues at hierarchical e-learning forms. The examination comprises of two segments. While the main area incorporates the writing about OD and Problem Solving Approach, the second incorporates the field look into on study about the karabuk college's moderately new online separation instruction (DE) program. Nadeem Ghafoor Chaudhry and Ghulam Rasool (2012) analyzed that each person ought to have critical thinking aptitudes so as to achieve one's coveted objectives throughout everyday life. Critical thinking abilities turn out to be much more imperative when practical arrangements are urgently expected to adapt to twin issues of developing shortage of assets and expanding populaces. Pragmatic critical thinking aptitudes, with clear financially reasonable, convenient and implementable arrangements are profoundly esteemed. Korn.R (2010) This investigation is an assessment of the Solomon R. Guggenheim educator craftsman residency program, Learning Through the Arts (LTA). It looks at the program's effect on fifth grade understudies' critical thinking abilities. Understudies arbitrarily appointed to treatment and control bunches took an interest in the Design-a-Chair movement in which they were given a sack of materials and 15 minutes to develop their very own seat outline. Panel Fulya Oner Armagan, Safak Ulucinar, Sagir Ayse, Yalcin Celik (2009) The author analysis that critical thinking is a piece of reasoning. There are a few stages of critical thinking. The main thing which is essential for taking care of individual and authoritative issues is the information of critical thinking process. Understudies who have learned critical thinking procedure can be effective in each phase of their lives by utilizing these aptitudes in discovering answers for the experienced troubles and issues. In this examination, the impact of understudies' critical thinking abilities on accomplishment in the synthetic response rate and the impact of temperature and focus on the response rate subjects is explored; understudies are from a few distinct offices.

\section{METHODOLOGY}

For the purpose of this study, descriptive research is used to portray accurately the public opinion on problem solving skills. Convenient sampling method is used to collect the samples. 1850 samples - sample size. Independent variables are gender, educational qualification, age. Dependent variables are Problem solving process, choice of overcoming the problem, level of agreeability towards factors towards Problem solving skills. Independent sample $\mathrm{t}$ test, chi square and ANOVA are the research tools used in this research.

\section{ANALYSIS AND DISCUSSION \& RESULTS}

Null Hypothesis (Ho): There is no significant association between the Problem-solving process and age of the respondents.

Alternate Hypothesis (H1): There is significant association between the Problem-solving process and age of the respondents.

Table 1: Cross tabulation - Problem solving process and age of the respondents

\begin{tabular}{|c|c|c|c|c|}
\hline & \multicolumn{2}{|c|}{ Process of Problem Solving } & \multirow[t]{2}{*}{ Total } \\
\hline & & Yes & No & \\
\hline \multirow{4}{*}{ Age } & Less than 30 years & 241 & 210 & 451 \\
\hline & $31-40$ years & 452 & 558 & 1010 \\
\hline & $41-50$ years & 149 & 124 & 273 \\
\hline & Above 50 years & 102 & 14 & 116 \\
\hline \multicolumn{2}{|c|}{ Total } & 944 & 906 & 1850 \\
\hline
\end{tabular}

Table 2: Chi square test - Problem solving process and age of the respondents \begin{tabular}{|l|c|c|cr|}
\hline & Value & df & $\begin{array}{c}\text { Asymp. Sig. (2- } \\
\text { sided) }\end{array}$ \\
\hline Pearson Chi-Square & $81.557^{\mathrm{a}}$ & 3 & .001 \\
\hline
\end{tabular} 
Using chi square test, it was found that $\mathrm{p}$ value is less than 0.05 , which shows that null hypothesis is rejected. Therefore, there is significant association between the problem-solving process and age of the respondents. It shows that age creates an impact on the Problem-solving process.

Null Hypothesis (Ho): There is no significant difference between the choice of overcoming problem and the gender.

Alternate Hypothesis (H1): There is significant difference between the choice of overcoming problem and the gender.

Table 3: Choice of overcoming problem and Gender

\begin{tabular}{|l|l|l|l|l|l|}
\hline & Gender & $\mathrm{N}$ & Mean & Std. Deviation & Std. Error Mean \\
\hline $\begin{array}{l}\text { overcoming } \\
\text { problem }\end{array}$ & Male & 816 & 2.43 & .735 & .026 \\
Female & 1034 & 2.60 & .702 & .022 \\
\hline
\end{tabular}

Table 4: Independent Sample t Test - Choice of overcoming problem and Gender

\begin{tabular}{|l|l|l|l|}
\hline & t & df & $\begin{array}{l}\text { Sig. (2- } \\
\text { tailed) }\end{array}$ \\
\hline Overcoming Problem & -5.061 & 1848 & .001 \\
\hline
\end{tabular}

Using Independent sample t test, it was found that $\mathrm{p}$ value is less than 0.05 , which shows that null hypothesis is rejected. Therefore, there is significant difference between overcoming problem and the gender. It shows that male and female have different opinion regarding overcoming problem in their day to day life.

Null Hypothesis (Ho): There is no significant difference in the mean scores of level of agreeability towards Problem solving skills among the educational qualification groups.

Alternate Hypothesis (H1): There is significant difference in the mean scores of level of agreeability towards Problem solving skills among the educational qualification groups.

\begin{tabular}{|c|c|c|c|c|c|c|}
\hline \multicolumn{7}{|c|}{ Qualification } \\
\hline & & $\begin{array}{l}\text { Sum of } \\
\text { Squares }\end{array}$ & $\mathrm{df}$ & Mean Square & $\mathrm{F}$ & Sig. \\
\hline \multirow{3}{*}{$\begin{array}{l}\text { Objective and a logical } \\
\text { person }\end{array}$} & \begin{tabular}{|l|} 
Between \\
Groups
\end{tabular} & 432.564 & 4 & 108.141 & 73.901 & .000 \\
\hline & \begin{tabular}{|l} 
Within Groups \\
\end{tabular} & 2699.845 & 1845 & 1.463 & & \\
\hline & \begin{tabular}{|l|} 
Total \\
\end{tabular} & 3132.409 & 1849 & & & \\
\hline \multirow{3}{*}{$\begin{array}{l}\text { Capable of solving my } \\
\text { problem without others } \\
\text { help }\end{array}$} & $\begin{array}{l}\text { Between } \\
\text { Groups }\end{array}$ & 349.501 & 4 & 87.375 & 107.662 & .000 \\
\hline & Within Groups & 1497.343 & 1845 & .812 & & \\
\hline & Total & 1846.844 & 1849 & & & \\
\hline \multirow{3}{*}{$\begin{array}{l}\text { Tend to focus on } \\
\text { immediate problems } \\
\text { and let others worry } \\
\text { about the distant future] }\end{array}$} & $\begin{array}{l}\text { Between } \\
\text { Groups }\end{array}$ & 154.635 & 4 & 38.659 & 39.395 & .000 \\
\hline & \begin{tabular}{|l} 
Within Groups \\
\end{tabular} & 1810.527 & 1845 & .981 & & \\
\hline & Total & 1965.162 & 1849 & & & \\
\hline \multirow{3}{*}{\begin{tabular}{|l|} 
Type of person who \\
normally solve \\
problems quickly \\
without wasting a lot of \\
time on details \\
\end{tabular}} & $\begin{array}{l}\text { Between } \\
\text { Groups }\end{array}$ & 250.477 & 4 & 62.619 & 73.140 & .000 \\
\hline & Within Groups & 1579.614 & 1845 & .856 & & \\
\hline & Total & 1830.091 & 1849 & & & \\
\hline \multirow{3}{*}{$\begin{array}{l}\text { Don't let problems } \\
\text { upset, no matter how } \\
\text { difficult they are }\end{array}$} & \begin{tabular}{|l|} 
Between \\
Groups
\end{tabular} & 398.976 & 4 & 99.744 & 95.242 & .000 \\
\hline & \begin{tabular}{|l} 
Within Groups \\
\end{tabular} & 1932.218 & 1845 & 1.047 & & \\
\hline & Total & 2331.194 & 1849 & & & \\
\hline
\end{tabular}

Using ANOVA, it was analysed whether the level of agreeability regarding the Problem solving

skills among the educational qualification groups. Since the $\mathrm{p}$ value of all the reasons are lesser than 0.05 , it was found that there is significant difference in the mean scores of level of agreeability towards Problem solving skills among the educational qualification groups.

\section{CONCLUSION}

This study explored whether problem solving skills will help each and every person to lead a peaceful and pleasant life. The findings of this study suggests that Problem solving ability is fundamental for everybody to prevail in their day to day life. Problem solving enables people to take a gander at circumstances from numerous sides, and after that envision a few distinctive approaches to react. This open procedure of reasoning presents thoughts and arrangements that grow the open doors for progress. organizations that create problem solving expertise among the representatives can see an expansion in cooperation and efficiency, and a decrease in conflict. It is concluded that Problem solving ability is fundamental for everybody to prevail in their life.

\section{REFERENCES}

1. Arma?an, Fulya Öner, ?afak Uluç?nar Sa??r, and Ay?e Yalç?n Çelik. 2009. "The Effects of Students' Problem Solving Skills on Their Understanding of Chemical Rate and Their Achievement on This Issue." Procedia - Social and Behavioral Sciences 1 (1): 2678-84.

2. Baird, Leonard L. 1982. "Review of Problem Solving Skills," November. https://onlinelibrary.wiley.com/doi/pdf/10.1002/j.23308516.1983.tb00016.x.

3. Bernik, Mojca, and Jasmina Žnidarši?. 2012. "Solving Complex Problems with Help of Experiential Learning." Organizacija 45 (3): 117-24.

4. Brockman, Julie 1. 2003. "The Problem with ProblemSolving Training in Industry." https://core.ac.uk/download/pdf/46954952.pdf.

5. Hämäläinen, Raija, Bram De Wever, Kari Nissinen, and Sebastiano Cincinnato. n.d. "Understanding Adults' Strong Problem-Solving Skills Based on PIAAC." Journal of Workplace Behavioral Health, 537-53.

6. Heppner, P. Paul, and P. Paul Heppner. 1978. "A Review of the Problem-Solving Literature and Its Relationship to the Counseling Process." Journal of Counseling Psychology 25 (5): 366-75.

7. Ji Young Kim , Dae Soo Choi, Chang-Soo Sung and Joo Y. Park. n.d. "The Role of Problem Solving Ability on Innovative Behavior and Opportunity Recognition in University Students." Journal of Open innovation:Technology,Market and Complexity. https://doi.org/10.1186/s40852-018-0085-4.

8. Karakaya, Abdullah, and Kasim Y?lmaz. 2013. "Problem Solving Approach at Organizational Development Activities: A Research at Karabuk University." Procedia - Social and Behavioral Sciences 99 (November): 32231.

9. Knippen, Jay T., and Thad B. Green. 1997. "Problem Solving." Journal of Workplace Learning 9 (3): 98-99.

10. Lisa Gueldenzoph Snyder Mark. 2008. "Teaching Critical Thinking and Problem Solving Skills." The Delta $\mathrm{Pi}$ Epsilon Journal https://www.google.co.in/url?sa=t\&source=web\&rct=j\& url=http://reforma.fen.uchile.cl/Pape.

11. Marquardt, Michael, and Roland K. Yeo. 2012 Breakthrough Problem Solving with Action Learning: Concepts and Cases. Stanford University Press. 